\title{
Hernia inguinoescrotal bilateral gigante
}

\author{
J.A. Suárez González, A.V. Núñez López, M. Vérez Vivero
}

Servicio de Urología. H. Da Costa. Burela. Lugo

Actas Urol Esp 2005; 29 (4): 437

$\mathrm{P}$

aciente que acude a Urgencias por retención aguda de orina. A la exploración se objetiva aumento de tamaño escrotal bilateral que impide visualizar meato uretral, con gran dificultad para el sondaje vesical (Figs. 1 y 2).

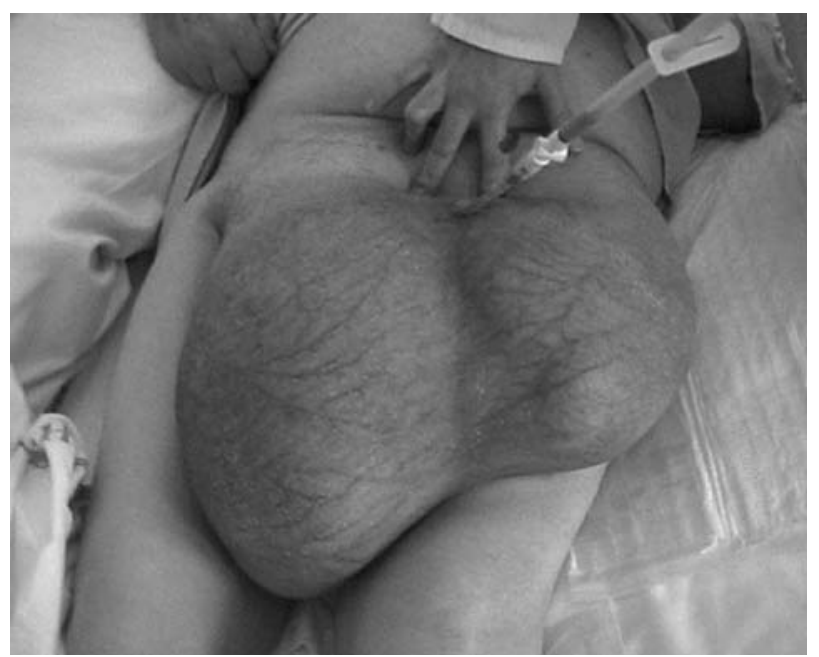

FIGURA 1
Se realiza TAC, observando gran hernia inginoescrotal bilateral (Fig. 3).

Dr. J.A. Suárez González

Servicio de Urología. Hospital da Costa

C/ Rafael Vior, s/n. - Burela (Lugo)

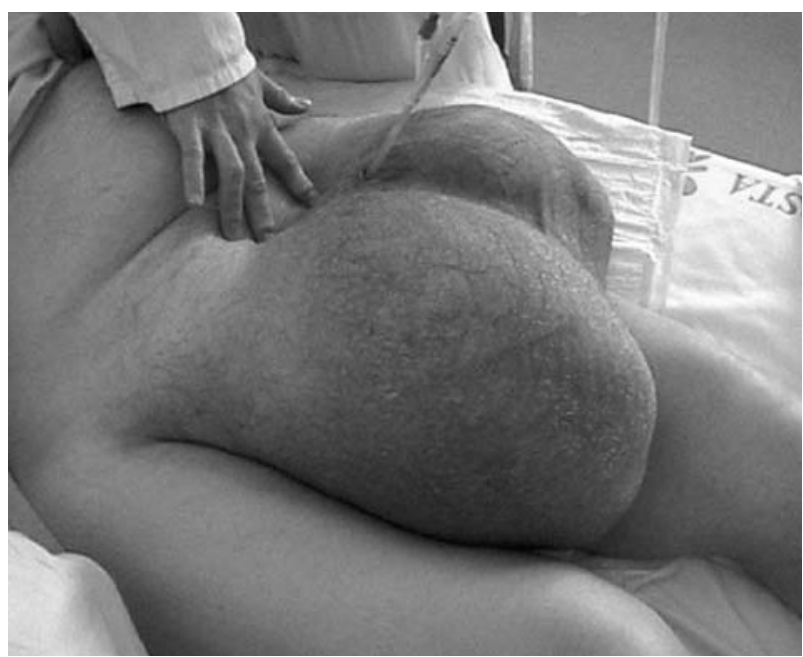

FIGURA 2

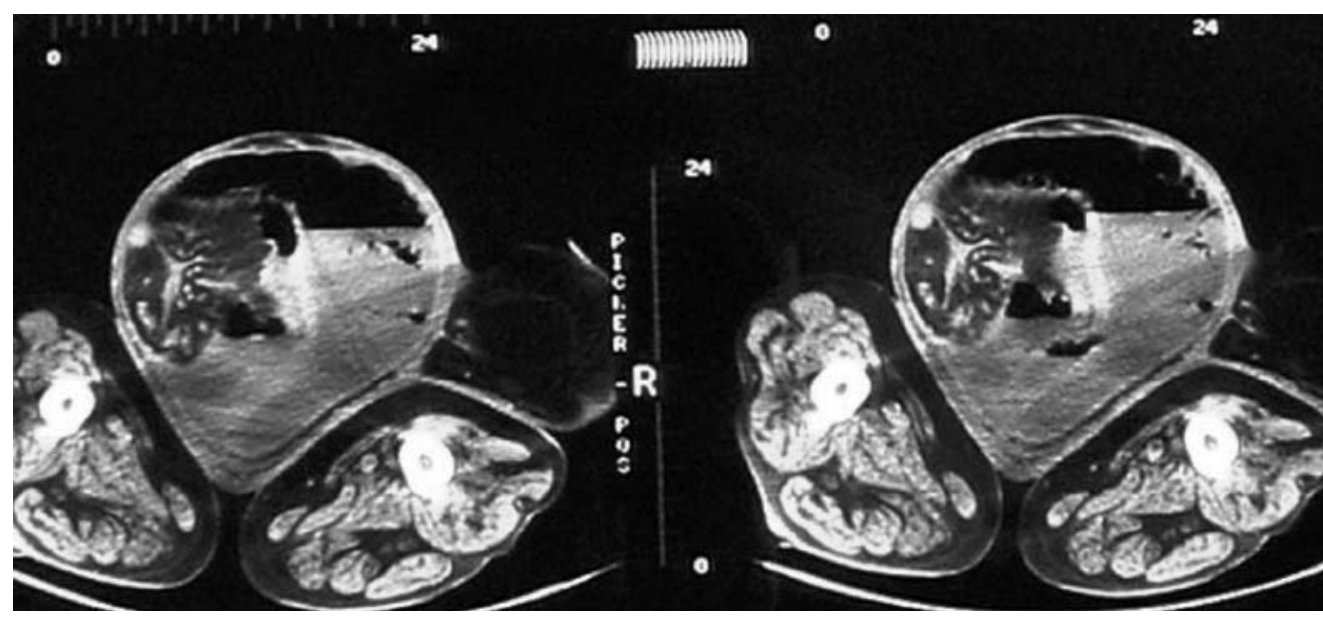

FIGURA 3 